\title{
Trakya-Marmara Bölgesi'nde İnsan Beslenmesine Uygun Yulaf (Avena sativa L.) Genotiplerinin Belirlenmesi
}

\author{
*Turhan KAHRAMAN ${ }^{1}$, Cengiz KURT'1 , Asiye SEIS SUBAȘI ${ }^{2}$, Tülin ÖZDEREN², \\ Özge YILDIZ ${ }^{3}$, Ceylan BÜYÜKKILECi ${ }^{3}$, Turgay SANAL ${ }^{2}$ \\ ${ }^{1}$ Trakya Tarımsal Araștırma Enstitüsü, Edirne \\ ${ }^{2}$ Tarla Bitkileri Merkez Araștırma Enstitüsü, Ankara \\ ${ }^{3}$ Ege Tarımsal Araștırma Enstitüsü, İzmir \\ *Sorumlu yazar e-posta (Corresponding author e-mail): turhankahraman@hotmail.com
}

\begin{abstract}
Öz
Bu çalıșma, 2014-2015 üretim sezonunda Kırklareli ve Edirne lokasyonlarında, altmıș dört yulaf genotipin kullanıldığı denemede, dört adet standart çeșit (Kırklar, Kahraman, Yeniçeri ve Sebat) yer almıștır. Deneme Üçlü Alfa Latis Deneme Desenine $(8$ × 8=64) göre üç tekerrürlü olarak yürütülmüștür. Araștırmada, Trakya Tarımsal Araștırma Enstitüsü tarafından geliștirilen yulaf genotiplerinin tane verimi ve bazı kalite özellikleri incelenerek insan beslenmesi açısından bölgeye uygun genotiplerin belirlenmesi amaçlanmıștır. Bu kapsamda genotiplerin tane verimi ile kalite özelliklerinden bin tane ağırlığı, hektolitre ağılığı, 2,2 mm elek üstü, kavuz oranı, tam tane yulafta protein, nișasta ve \% $\beta$-glukan miktarları incelenmiștir. Araștırma sonucunda iki lokasyonda da tane verimi yönünden genotipler arasındaki fark istatistiki olarak önemli bulunmuștur. İncelenen kalite özellikleri yönünden genotipler arasında farkllliklar belirlenmiștir. Kırklareli lokasyonunda genotiplerin tane verimi; 369.7-865.0 (682.1) $\mathrm{kg} / \mathrm{da}$, bin tane ağırlı̆ı 22.2-41.4 (31.6) $\mathrm{g}$, hektolitre ağırlığı 48.2-58.6 (52.5) kg/hl, $2.2 \mathrm{~mm}$ elek üstü \%20.0-96.3 (71.8), kavuz oranı \%20.6-39.2 (29.9), protein \%14.5-20.2 (17.8), nișasta \%49.5-61.2 (56,1) ve $\beta$-glukan miktarı \%3.5-5.9 (4.6) arasında belirlenmiștir. Edirne lokasyonunda ise tane verimi $116.4-751.3(630.9) \mathrm{kg} / \mathrm{da}$, bin tane ağırlığı 23.1-39.4 (31.7) g, hektolitre ağırlı̆ı 44.6-56.7 (52.0) kg/hl, 2.2 mm elek üstü \%23.1-95.4 (68.5), kavuz oranı \%17.0-39.5 (26.3), protein \%17.3-22.4 (20.1), nișasta \%47.7-57.3 (52.9) ve $\beta$-glukan miktarı \%3.9-5.8 (4.8) arasında değișim göstermiștir. Tane verimi ve incelenen kalite özellikleri yönünden Kırklareli lokasyonunda; 11, 14, 15, 16, 21 ve 22 nolu hatlar ile Kahraman çeșidi, Edirne lokasyonunda ise 11, 14, 15, 16 ve 38 nolu hatlar ile Kahraman çeșidi öne çıkmıștır. Trakya-Marmara Bölgesi'nde insan beslenmesi açısından 11, 14, 15 ve 16 nolu hatlar ile Kahraman çeșidinin uygun olduğu belirlenmiștir.
\end{abstract}

Anahtar Kelimeler: Yulaf (Avena sativa L.), tane verimi, insan beslenmesi, kalite özellikleri

\section{Determination of Oat (Avena sativa L.) Genotypes Suitable for Human Nutrition in Trakya-Marmara Region}

\section{Abstract}

This study was carried out in 2014-2015 cropping year in Edirne and KIrklareli locations with 60 oat lines and 4 commercial varieties (Kırklar, Kahraman, Yeniçeri and Sebat). The experiment was established in an alpha lattice experimental design technique $(8 \times 8=64)$ with three replications. In the research, it was aimed to determine genotypes of the region suitable for human nutrition by examining yield and some quality parameter performances of oat genotypes developed by Thrace Agricultural Research Institute. The traits such as grain yield (GY), thousand kernel weight (TKW), test weight (TW), plumpness (P, sieved $2.2 \mathrm{~mm}$ slotted), husk rate (HR), full grain oat protein (FGOP), starch (S), and $\beta$-glucan ( $\beta-G)$ content of genotypes were investigated. The variations among oat lines for grain yield was significant and differences for TKW, TW, P, HR, FGOP, S, and $\beta-G$ were also determined. The GY, TKW, TW, P, HR, FGOP, S, and $\beta-G$ of oat lines ranged between $369.7-865.0(682.1) \mathrm{kg} / \mathrm{da}, 22.2-41.4$ (31.6) g, 48.2-58.6 (52.5) kg/hl, 20.0-96.3\% (71.8), 20.6-39.2\% (29.9), 14.5-20.2\% (17.8), 49.5-61.2\% (56.1), and 3.5-5.9\% (4.6) in Kirklareli location; and 116.4-751.3 (630.9) kg/da, 23.1-39.4 (31.7) g, 44.6-56.7 (52.0) kg/hl, 23.1-95.4\% (68.5), 17.0-39.5\% (26.3), $17.3-22.4 \%$ (20.1), 47.7-57.3\% (52.9), and 3.9-5.8\% (4.8) in Edirne location, respectively. The promising oat lines in the experiment were 11, 14, 15, 16, 21, 22 and CV Kahraman in Kırklareli; and 11, 14, 15, 16, 38, and CV Kahraman in Edirne location regarding their grain yield and other quality parameters. The oat lines 11, 14, 15, 16, and CV Kahraman were suitable in terms of human nutrition in Trakya-Marmara region.

Keywords: Oat (Avena sativa L.), grain yield, human nutrition, quality traits 


\section{Giriș}

Y ulafın insan beslenmesinde daha fazla yer alması, daha verimli ve kaliteli yulaf çeșitlerinin endüstriye kazandırılması önem arz etmektedir (Buerstmayr et al., 2007).

Sağlıklı yașam açısından son derece önemli bir tahıl olan yulafın ülkemizde daha fazla tüketilmesi, tüketim alanlarının çeșitlendirilmesi, bölgelere uygun, verimi yüksek, yatma ve hastalıklara dayanıklı tescilli yulaf çeșitlerinin geliștirilmesi gerekmektedir. Hayvan beslenmesinde yüksek protein ve yağ miktarı ile düșük $\beta$-glukan istenirken, insan beslenmesinde yüksek protein ve $\beta$-glukan miktarı ile düșük yağ miktarı istenmektedir.

Gıda sanayicisi kaliteli ürün elde edebilmesi için kaliteli yulafa intiyacı vardır. Sanayici kaliteli yulaf tanımını "kavuz oranı düșük ve kolay ayrılabilir, randımanı ise yüksek" șeklinde ifade etmektedir. Ayrıca yağ oranının yüksek olması ürünün raf ömrünü kısalttığından dolayı yulafta yağ oranının yüksek olması istenmez. Eti $A$. Ș. yulaf alımı yaparken yulafta bin tane ağırlığının en az $26 \mathrm{~g}$, hektolitre ağırlığının ise $46 \mathrm{~kg} / \mathrm{hl}$, soyulmuș ve kırık tane oranının en fazla $\% 5$, $2 \mathrm{~mm}$ elek üstünün ise en az \%50 ve $1.5 \mathrm{~mm}$ elek altının en fazla $\% 5$ olmasını istemektedir.

Gıda sanayicisi yulafın bir kısmını yulaf unu halinde yulafı bisküvilerde ve bir kısmını da yulaf ezmesi olarak müsli yiyeceklerde (kahvaltılık) kullanmaktadır.

Dünya tahıl üretiminde yulaf 9,608 milyon ha ekim alanında, 22,7 milyon ton üretim ile buğday, mısır, çeltik, arpa ve sorgumdan sonra gelmektedir (Anonim, 2014). Tamm (2003) ve Buerstmyr et al. (2007) yaptıkları çalıșmalarda iklim șartlarının (özellikle sıcaklık ve yağıș miktarı ve dağılımı) yulafta tane verimi, verim unsurları ve kalite özellikleri üzerine önemli derecede etkisi olduğunu bildirmișlerdir. Yulafta hektolitre ağırlığı ile iç oranı arasında yüksek bir ilișki olduğunu belirlemișlerdir (Doehlert et al., 2001; Peterson et al., 2005).

Avrupa'da yulafın \%10 kadarı insan beslenmesinde kullanılmaktadır. Geleneksel kahvaltılık olan yulaf günümüzde makarna, ekmek, bisküvi, kek ve atıștırmalık ürünlerde gıda olarak tüketilmektedir. Yulaf özellikle gluten içermemesi nedeni ile glutensiz gıda ile beslenmek zorunda olan çölyak hastaları için iyi bir alternatiftir. Yulafın tane verimi ve kalitesi ürünün değerini belirlemektedir. Yulafın kalitesini kimyasal bileșimi belirler. Kimyasal bileșimi ise karbonhidrat, protein, yağ, vitamin, mineral vb. miktarına bağlı olup; bitkinin yetiștirildiği ekolojik koșullar, çeșit ve hasat sonrası ișlemler gibi pek çok faktöre bağlı olarak değișir. Yulaf proteinleri, esansiyel aminoasit içermesiyle biyolojik değeri yüksek proteine sahiptir (Anderson, 2000).

Araștırmada, Trakya Tarımsal Araștırma Enstitüsü tarafından geliștirilen yulaf genotiplerin insan beslenmesi açısından bölgeye uygun genotiplerin belirlenmesi amacıyla genotiplerin tane verimi ile kalite özelliklerinden bin tane ağırlığı, hektolitre ağırlığı, $2.2 \mathrm{~mm}$ elek üstü, kavuz oranı, tam tane yulafta protein, nișasta ve $\% \beta$-glukan miktarları incelenmiștir.

\section{Materyal ve Yöntem}

2014-2015 üretim sezonunda Kırklareli ve Edirne lokasyonlarında yürütülen bu araștırma dört sandart çeșit (Kırklar, Kahraman, Yeniçeri ve Sebat) ile ıslah çalıșmaları sonucu geliștirilen altmıș ileri kademe yulaf hattından kurulmuștur. Deneme, Üçlü Latis Deneme Deseni'ne $(8 \times 8$ = 64) göre üç tekerrürlü olarak yürütülmüștür.

Ekim, $\mathrm{m}^{2}$ ye 500 adet tohum olacak șekilde $7 \mathrm{~m} \times 1 \mathrm{~m}=7 \mathrm{~m}^{2}$ parsellere özel ekim mibzeriyle yapılmıștır. Hasatta ise parseller $6 \mathrm{~m} \times 1 \mathrm{~m}=6$ $\mathrm{m}^{2}$ alan üzerinden değerlendirilmiștir.

Hasat sonrası bin tane ağırlığı, hektolitre ağırığı ve protein oranı gibi kalite analizleri yapılmıștır. Örneklerde hektolitre ağırlığı ve bin tane ağırlı̆ı Uluöz'e (1965) göre, protein oranı (azot oranı * 5.83) AOAC 992.23 metoduyla ve LECO FP 528 azot tayin cihazı ile belirlenmiștir (Anonim, 2009).

\section{Bulgular ve Tartıșma}

Genotiplerin tane verimi, bin tane ve hektolitre ağırlığı ile ilgili veriler Çizelge 1'de, $2.2 \mathrm{~mm}$ elek üstü, kavuz oranı, protein oranı, nișasta miktarı ve $\beta$-glukan değerleri ise Çizelge 2'de verilmiștir. Kırklareli lokasyonundaki genotiplerin tane verimleri $369.7-865.0 \mathrm{~kg} / \mathrm{da}$ arasında değișim göstermiș, $865.0 \mathrm{~kg} / \mathrm{da}$ tane 
Çizelge 1. Altmıș dört yulaf genotipin iki lokasyondaki tane verimi, bin tane ve hektolitre ağırlığı değerleri Table 1. Mean performance of 64 oat genotypes for grain yield, thousand kernel weight and test weight at 2 locations

\begin{tabular}{|c|c|c|c|c|c|c|c|}
\hline \multirow[t]{2}{*}{$\begin{array}{l}\text { Sira } \\
\text { No }\end{array}$} & \multirow[t]{2}{*}{ Çeșit veya Pedigri } & \multicolumn{2}{|c|}{$\begin{array}{c}\text { Tane Verimi } \\
(\mathrm{kg} / \mathrm{da})\end{array}$} & \multicolumn{2}{|c|}{$\begin{array}{c}\text { Bin Tane Ağ. } \\
(\mathrm{g})\end{array}$} & \multicolumn{2}{|c|}{$\begin{array}{c}\text { Hektolitre Ağ. } \\
(\mathrm{kg})\end{array}$} \\
\hline & & Kırklareli & Edirne & Kırklareli & Edirne & Kırklareli & Edirne \\
\hline 1 & KIRKLAR (ST) & 758.8 & 600.3 & 31.8 & 32.8 & 54.4 & 56.6 \\
\hline 2 & Bw 4903-0BD-0T-7T-0T & 655.2 & 664.7 & 35.2 & 33.5 & 48.7 & 51.4 \\
\hline 3 & FL04167-0BD-0T-0T-1T-0T & 803.3 & 575.5 & 26.8 & 28.1 & 50.7 & 51.3 \\
\hline 4 & FL04169-0BD-0T-0T-8T-0T & 773.5 & 670.0 & 29.5 & 32.0 & 52.9 & 53.2 \\
\hline 5 & FL04109-0BD-0T-0T-5T-0T & 803.3 & 629.3 & 27.7 & 28.3 & 53.1 & 53.0 \\
\hline 6 & FL0549-0BD-0T-0T-2T-0T & 821.7 & 700.3 & 31.2 & 31.4 & 53.0 & 52.5 \\
\hline 7 & Bw 103-0BD-0T-7T-0T & 865.0 & 666.8 & 33.9 & 31.2 & 49.1 & 47.5 \\
\hline 8 & Bw 1103-0BD-0T-3T-0T & 806.8 & 715.2 & 29.3 & 34.7 & 49.3 & 52.5 \\
\hline 9 & Ave.98.01-0BD-0T-9T-0T & 610.5 & 629.0 & 38.1 & 29.8 & 51.3 & 54.6 \\
\hline 10 & FL0557-0BD-0T-0T-1T-0T & 766.8 & 619.5 & 40.2 & 38.8 & 53.5 & 53.7 \\
\hline 11 & FL04109-0BD-0T-0T-11T-0T & 832.3 & 663.5 & 29.6 & 28.4 & 53.1 & 51.9 \\
\hline 12 & IL 3555-0BD-0T-5T-0T & 643.7 & 680.8 & 31.0 & 30.2 & 52.5 & 50.8 \\
\hline 13 & Bw 1103-0BD-0T-6T-0T & 799.5 & 707.5 & 31.5 & 34.7 & 52.5 & 51.5 \\
\hline 14 & FL04167-0BD-0T-0T-9T-0T & 796.7 & 671.3 & 27.7 & 29.8 & 54.8 & 54.4 \\
\hline 15 & FL04144-0BD-0T-0T-5T-0T & 811.5 & 751.3 & 30.9 & 31.9 & 53.9 & 53.2 \\
\hline 16 & FL04146-0BD-0T-0T-2T-0T & 815.8 & 676.7 & 30.1 & 32.0 & 55.6 & 55.8 \\
\hline 17 & FL04167-0BD-0T-0T-10T-0T & 757.2 & 660.7 & 26.8 & 29.7 & 54.6 & 53.8 \\
\hline 18 & FL0507-0BD-0T-0T-7T-0T & 699.3 & 617.7 & 28.6 & 26.3 & 55.8 & 54.9 \\
\hline 19 & FL0557-0BD-0T-0T-3T-0T & 800.2 & 609.8 & 33.7 & 37.7 & 51.8 & 51.4 \\
\hline 20 & KAHRAMAN (ST) & 780.2 & 651.0 & 33.7 & 34.9 & 58.6 & 54.9 \\
\hline 21 & FL0557-0BD-0T-0T-5T-0T & 823.5 & 611.3 & 37.5 & 39.4 & 58.2 & 54.6 \\
\hline 22 & FL0568-0BD-0T-0T-5T-0T & 828.2 & 635.7 & 31.3 & 33.6 & 56.2 & 54.0 \\
\hline 23 & Bw 103-0BD-0T-3T-0T & 777.2 & 650.3 & 33.3 & 32.0 & 52.1 & 46.1 \\
\hline 24 & IL 3555-0BD-0T-1T-0T & 704.8 & 657.8 & 31.5 & 33.4 & 51.3 & 51.8 \\
\hline 25 & FL0550-0BD-0T-0T-7T-0T & 657.5 & 656.3 & 31.6 & 33.3 & 55.9 & 53.6 \\
\hline 26 & FL99078-H1-0BD-0T-5T-0T & 677.7 & 662.7 & 22.8 & 27.1 & 56.2 & 55.9 \\
\hline 27 & Bw 103-0BD-0T-2T-0T & 750.5 & 582.5 & 31.7 & 34.4 & 53.1 & 50.1 \\
\hline 28 & FL0016-H1-0BD-0T-1T-0T & 729.8 & 626.7 & 22.2 & 25.8 & 54.9 & 54.0 \\
\hline 29 & FL97107-C3-G1-0BD-3T-0T & 536.8 & 593.7 & 29.0 & 29.4 & 52.7 & 50.1 \\
\hline 30 & FL04133-0BD-0T-0T-1T-0T & 694.3 & 689.2 & 27.5 & 33.7 & 53.2 & 53.1 \\
\hline 31 & FL04144-0BD-0T-0T-3T-0T & 708.3 & 675.8 & 28.9 & 29.3 & 53.3 & 53.8 \\
\hline 32 & FL04149-0BD-0T-0T-1T-0T & 699.7 & 663.8 & 37.4 & 34.9 & 57.1 & 56.6 \\
\hline 33 & MN06203-0BD-0T-11T-3T-0T & 449.0 & 614.8 & 27.0 & 26.3 & 51.8 & 48.8 \\
\hline 34 & FL0552-0BD-0T-0T-5T-0T & 664.8 & 606.2 & 32.7 & 30.8 & 49.4 & 51.1 \\
\hline 35 & FL0552-0BD-0T-0T-7T-0T & 694.7 & 587.7 & 33.2 & 29.7 & 50.7 & 46.6 \\
\hline 36 & FL0548-0BD-0T-0T-6T-0T & 651.2 & 572.3 & 31.2 & 34.7 & 55.1 & 54.6 \\
\hline 37 & IA 01160-3-1-0BD-0T-2T-0T & 431.2 & 574.0 & 30.2 & 31.8 & 53.3 & 48.7 \\
\hline 38 & FL04109-0BD-0T-0T-8T-0T & 763.0 & 695.3 & 27.7 & 31.2 & 54.4 & 49.2 \\
\hline 39 & FL0552-0BD-0T-0T-1T-0T & 657.0 & 653.5 & 34.2 & 29.5 & 50.5 & 49.1 \\
\hline 40 & YENIÇERI (ST) & 688.8 & 659.8 & 24.7 & 24.5 & 51.5 & 52.2 \\
\hline 41 & FL0503-0BD-0T-0T-4T-0T & 609.7 & 718.7 & 35.6 & 32.8 & 53.5 & 54.3 \\
\hline 42 & FL0520-0BD-0T-0T-1T-0T & 662.3 & 520.7 & 30.5 & 27.8 & 53.2 & 56.0 \\
\hline 43 & FL0516-0BD-0T-0T-3T-0T & 811.5 & 655.2 & 28.0 & 28.8 & 52.7 & 53.5 \\
\hline 44 & FL0516-0BD-0T-0T-7T-0T & 785.3 & 720.0 & 30.9 & 30.3 & 52.4 & 54.9 \\
\hline 45 & FL0517-0BD-0T-0T-6T-0T & 680.2 & 542.8 & 26.2 & 31.2 & 48.2 & 45.8 \\
\hline 46 & FL0520-0BD-0T-0T-5T-0T & 692.0 & 570.7 & 35.1 & 25.3 & 52.2 & 51.6 \\
\hline 47 & FL0520-0BD-0T-0T-9T-0T & 648.0 & 566.8 & 30.5 & 36.8 & 54.2 & 51.0 \\
\hline 48 & FL0523-0BD-0T-0T-11T-0T & 710.2 & 629.5 & 29.0 & 30.9 & 50.3 & 50.1 \\
\hline 49 & FL0525-0BD-0T-0T-1T-0T & 704.5 & 598.2 & 32.4 & 28.3 & 52.3 & 56.7 \\
\hline 50 & FL06010-0BD-0T-0T-7T-0T & 486.0 & 713.5 & 36.6 & 33.7 & 53.9 & 54.1 \\
\hline 51 & FL06010-0BD-0T-0T-8T-0T & 369.7 & 600.7 & 33.1 & 37.7 & 50.7 & 50.2 \\
\hline 52 & P 0216A1-1-0BD-0T-2T-0T & 382.5 & 116.4 & 37.6 & 27.7 & 49.2 & 50.1 \\
\hline 53 & FL0565-0BD-0T-0T-2T-0T & 540.0 & 642.7 & 40.3 & 37.4 & 48.8 & 49.4 \\
\hline 54 & FL0522-0BD0T-0T-7T-0T & 549.7 & 696.2 & 38.6 & 38.0 & 48.3 & 49.0 \\
\hline 55 & FL0543-0BD-0T-0T-3T-0T & 732.7 & 695.0 & 28.6 & 30.1 & 55.3 & 56.7 \\
\hline 56 & FL0516-0BD-0T-0T-8T-0T & 736.7 & 702.5 & 29.2 & 28.9 & 50.7 & 53.5 \\
\hline 57 & FL0530-0BD-0T-0T-2T-0T & 380.7 & 504.5 & 32.4 & 31.6 & 53.0 & 51.4 \\
\hline 58 & FL0532-0BD-0T-0T-10T-0T & 627.3 & 693.5 & 41.4 & 38.8 & 51.1 & 53.6 \\
\hline 59 & FL06006-0BD-0T-0T-6T-0T & 707.0 & 603.0 & 35.8 & 35.9 & 54.8 & 54.2 \\
\hline 60 & SEBAT (ST) & 733.3 & 637.2 & 23.4 & 23.1 & 50.7 & 46.0 \\
\hline 61 & FL0522-0BD0T-0T-5T-0T & 505.5 & 662.3 & 36.7 & 35.6 & 48.8 & 44.6 \\
\hline 62 & FL0522-0BD0T-0T-10T-0T & 536.8 & 589.2 & 36.8 & 35.9 & 49.9 & 48.1 \\
\hline 63 & FL0523-0BD-0T-0T-3T-0T & 574.0 & 552.5 & 25.2 & 26.7 & 50.6 & 54.1 \\
\hline 64 & FL0523-0BD-0T-0T-6T-0T & 496.7 & 612.3 & 33.5 & 33.3 & 48.9 & 49.4 \\
\hline Denen & rit. (kg/da) & 682.1 & 630.9 & 31.6 & 31.7 & 52.5 & 52.0 \\
\hline A. Ö. & SD: 0.05) (kg/da) & 86.5 & 66.7 & & & & \\
\hline D. K $(($ & $(\%)$ & 7.85 & 6.52 & & & & \\
\hline
\end{tabular}


Çizelge 2. Altmıș dört yulaf genotipin iki lokasyondaki $2.2 \mathrm{~mm}$ elek üstü, kavuz oranı, protein oranı, nișasta miktarı ve $\beta$-glukan değerleri

Table 2. Mean performance of 64 oat genotypes for plumpness ( $P$, sieved $2.2 \mathrm{~mm}$ slotted), husk rate, protein ratio, starch and b-glucan content at 2 locations

\begin{tabular}{|c|c|c|c|c|c|c|c|c|c|c|}
\hline \multirow[t]{2}{*}{$\begin{array}{l}\text { Sira } \\
\text { No }\end{array}$} & \multicolumn{2}{|c|}{$\begin{array}{c}\text { Kavuz Oranı } \\
(\%)\end{array}$} & \multicolumn{2}{|c|}{$\begin{array}{c}2.2 \text { mm elek üstü } \\
(\%)\end{array}$} & \multicolumn{2}{|c|}{$\begin{array}{c}\text { Protein Oranı } \\
(\%)\end{array}$} & \multicolumn{2}{|c|}{$\begin{array}{c}\text { Nișasta Miktarı } \\
(\%)\end{array}$} & \multicolumn{2}{|c|}{$\begin{array}{l}\beta \text {-glukan } \\
(\%)\end{array}$} \\
\hline & Kırklareli & Edirne & Kırklareli & Edirne & Kırklareli & Edirne & Kırklareli & Edirne & Kırklareli & Edirne \\
\hline 1 & 28.6 & 21.1 & 66.8 & 70.5 & 17.5 & 19.8 & 53.1 & 52.8 & 4.4 & 4.4 \\
\hline 2 & 30.5 & 31.2 & 83.9 & 88.7 & 19.8 & 19.5 & 57.3 & 50.4 & 4.4 & 4.1 \\
\hline 3 & 31.7 & 27.2 & 55.9 & 74.6 & 19.5 & 21.9 & 53.0 & 51.1 & 4.5 & 4.8 \\
\hline 4 & 30.9 & 27.6 & 64.8 & 75.9 & 18.0 & 20.4 & 53.2 & 53.4 & 4.0 & 4.1 \\
\hline 5 & 27.2 & 24.8 & 65.0 & 71.0 & 17.0 & 18.4 & 55.5 & 55.5 & 4.6 & 4.4 \\
\hline 6 & 32.0 & 24.7 & 77.9 & 76.6 & 19.2 & 20.2 & 52.4 & 53.0 & 5.2 & 4.8 \\
\hline 7 & 27.9 & 26.1 & 84.6 & 81.2 & 18.4 & 20.2 & 51.8 & 50.3 & 5.7 & 5.9 \\
\hline 8 & 29.4 & 23.4 & 83.6 & 90.4 & 17.7 & 20.3 & 51.1 & 49.5 & 5.7 & 5.7 \\
\hline 9 & 28.3 & 20.4 & 75.6 & 81.0 & 19.5 & 22.4 & 48.7 & 50.5 & 5.4 & 4.9 \\
\hline 10 & 26.3 & 21.7 & 93.0 & 91.8 & 18.1 & 20.6 & 50.0 & 51.3 & 5.1 & 5.0 \\
\hline 11 & 29.5 & 24.9 & 72.9 & 64.3 & 16.9 & 19.8 & 49.6 & 51.2 & 5.6 & 4.8 \\
\hline 12 & 35.0 & 27.4 & 67.8 & 54.6 & 17.1 & 19.4 & 53.5 & 61.2 & 5.1 & 4.6 \\
\hline 13 & 34.9 & 27.5 & 87.8 & 90.4 & 17.9 & 19.4 & 54.8 & 53.5 & 5.6 & 5.9 \\
\hline 14 & 25.3 & 31.9 & 60.9 & 76.9 & 17.9 & 21.2 & 52.5 & 53.5 & 4.8 & 5.3 \\
\hline 15 & 28.5 & 29.3 & 81.7 & 79.3 & 16.4 & 18.3 & 47.7 & 59.7 & 5.2 & 5.4 \\
\hline 16 & 24.2 & 17.0 & 80.7 & 87.2 & 16.2 & 17.8 & 56.4 & 57.3 & 4.9 & 4.9 \\
\hline 17 & 31.2 & 25.7 & 73.3 & 76.9 & 18.9 & 20.2 & 50.8 & 51.4 & 4.5 & 5.2 \\
\hline 18 & 26.0 & 27.6 & 68.6 & 69.0 & 18.4 & 20.8 & 48.2 & 57.3 & 4.6 & 5.0 \\
\hline 19 & 30.3 & 25.6 & 84.9 & 93.8 & 18.5 & 21.7 & 53.0 & 56.4 & 4.2 & 4.2 \\
\hline 20 & 26.6 & 22.3 & 92.4 & 94.9 & 17.7 & 21.3 & 50.1 & 57.4 & 5.3 & 5.3 \\
\hline 21 & 27.8 & 21.9 & 92.2 & 93.7 & 16.7 & 20.5 & 54.2 & 56.1 & 4.5 & 5.2 \\
\hline 22 & 31.8 & 22.6 & 81.3 & 81.9 & 18.2 & 20.7 & 53.4 & 58.6 & 4.3 & 4.6 \\
\hline 23 & 39.2 & 31.3 & 83.0 & 78.9 & 17.3 & 19.7 & 50.6 & 54.3 & 5.8 & 5.8 \\
\hline 24 & 32.6 & 25.9 & 73.5 & 70.5 & 16.1 & 19.2 & 56.7 & 55.3 & 5.6 & 5.5 \\
\hline 25 & 26.9 & 20.4 & 84.2 & 85.1 & 17.0 & 18.9 & 55.7 & 54.9 & 4.4 & 4.7 \\
\hline 26 & 30.8 & 25.4 & 21.5 & 51.2 & 18.4 & 19.3 & 56.2 & 58.5 & 4.4 & 4.7 \\
\hline 27 & 31.8 & 28.1 & 76.6 & 90.5 & 18.5 & 19.6 & 56.2 & 56.6 & 5.6 & 5.4 \\
\hline 28 & 34.2 & 26.4 & 20.0 & 46.9 & 19.3 & 19.5 & 53.4 & 53.1 & 4.6 & 4.6 \\
\hline 29 & 26.3 & 29.0 & 63.8 & 66.3 & 18.5 & 20.2 & 54.7 & 58.5 & 4.8 & 4.4 \\
\hline 30 & 24.8 & 26.2 & 39.1 & 63.6 & 18.3 & 18.8 & 54.1 & 57.6 & 4.8 & 4.6 \\
\hline 31 & 26.5 & 27.5 & 88.6 & 93.3 & 17.8 & 18.6 & 56.6 & 57.3 & 4.9 & 4.9 \\
\hline 32 & 29.0 & 31.3 & 92.9 & 93.8 & 17.2 & 20.3 & 55.6 & 57.9 & 4.5 & 4.1 \\
\hline 33 & 31.2 & 27.5 & 56.9 & 47.0 & 18.5 & 21.0 & 54.9 & 53.6 & 4.2 & 3.5 \\
\hline 34 & 31.4 & 30.1 & 71.7 & 61.9 & 15.4 & 18.0 & 54.1 & 60.4 & 5.1 & 4.6 \\
\hline 35 & 23.7 & 28.0 & 83.3 & 77.0 & 15.6 & 20.1 & 51.7 & 60.1 & 5.3 & 4.7 \\
\hline 36 & 30.3 & 29.3 & 71.9 & 69.4 & 16.1 & 20.4 & 50.0 & 58.3 & 4.7 & 4.5 \\
\hline 37 & 30.1 & 29.0 & 51.7 & 37.7 & 18.4 & 18.8 & 54.2 & 56.6 & 5.2 & 4.9 \\
\hline 38 & 27.1 & 26.8 & 74.4 & 87.4 & 18.4 & 20.0 & 53.4 & 57.9 & 4.6 & 4.4 \\
\hline 39 & 33.3 & 27.3 & 77.6 & 61.6 & 18.2 & 19.4 & 50.0 & 58.0 & 5.4 & 4.5 \\
\hline 40 & 31.4 & 24.0 & 29.0 & 26.5 & 17.0 & 17.3 & 55.3 & 58.1 & 4.3 & 3.8 \\
\hline 41 & 29.4 & 24.3 & 82.5 & 77.3 & 18.8 & 21.9 & 54.5 & 55.7 & 4.7 & 4.0 \\
\hline 42 & 31.3 & 24.6 & 51.4 & 66.8 & 16.9 & 21.1 & 52.4 & 60.3 & 4.8 & 4.3 \\
\hline 43 & 35.7 & 28.8 & 67.9 & 62.7 & 19.6 & 20.9 & 51.1 & 53.5 & 5.3 & 4.5 \\
\hline 44 & 39.2 & 24.5 & 59.9 & 63.2 & 17.9 & 21.0 & 50.2 & 57.4 & 5.3 & 4.5 \\
\hline 45 & 27.3 & 21.5 & 77.8 & 83.1 & 18.0 & 22.0 & 50.6 & 58.0 & 4.8 & 4.3 \\
\hline 46 & 27.0 & 25.9 & 47.3 & 53.2 & 15.8 & 20.7 & 49.6 & 57.5 & 4.9 & 4.0 \\
\hline 47 & 35.2 & 28.3 & 77.6 & 87.5 & 19.3 & 22.4 & 49.4 & 55.2 & 4.9 & 4.5 \\
\hline 48 & 31.5 & 26.4 & 77.6 & 84.3 & 16.9 & 18.9 & 54.6 & 58.9 & 4.7 & 4.5 \\
\hline 49 & 30.5 & 25.3 & 60.7 & 57.8 & 18.3 & 19.2 & 52.5 & 56.9 & 4.8 & 4.8 \\
\hline 50 & 26.7 & 23.8 & 73.2 & 69.8 & 17.8 & 20.0 & 50.4 & 57.3 & 4.9 & 4.8 \\
\hline 51 & 34.4 & 29.2 & 91.9 & 92.8 & 18.0 & 19.2 & 51.1 & 58.7 & 4.6 & 4.4 \\
\hline 52 & 34.3 & 39.5 & 84.0 & 78.8 & 18.5 & 19.8 & 55.3 & 59.9 & 5.0 & 4.0 \\
\hline 53 & 30.4 & 28.2 & 91.4 & 87.8 & 19.9 & 22.1 & 51.3 & 55.6 & 4.6 & 4.3 \\
\hline 54 & 33.3 & 24.1 & 94.9 & 89.1 & 20.2 & 20.7 & 53.4 & 55.9 & 4.8 & 4.2 \\
\hline 55 & 26.2 & 19.6 & 43.2 & 39.0 & 14.5 & 18.0 & 55.3 & 61.1 & 5.7 & 4.6 \\
\hline 56 & 31.2 & 29.1 & 60.9 & 55.7 & 17.4 & 20.9 & 53.6 & 53.1 & 5.2 & 4.4 \\
\hline 57 & 31.3 & 23.8 & 82.6 & 76.9 & 18.7 & 21.8 & 53.1 & 57.8 & 4.4 & 3.9 \\
\hline 58 & 33.3 & 27.9 & 96.3 & 95.9 & 18.5 & 21.4 & 54.6 & 59.0 & 4.4 & 4.5 \\
\hline 59 & 20.6 & 22.2 & 90.1 & 86.1 & 18.3 & 21.2 & 50.5 & 54.0 & 4.7 & 4.5 \\
\hline 60 & 35.4 & 26.3 & 25.6 & 23.1 & 14.8 & 19.0 & 54.9 & 60.7 & 4.0 & 3.8 \\
\hline 61 & 28.3 & 33.3 & 93.9 & 83.5 & 19.7 & 22.1 & 53.2 & 56.9 & 4.5 & 4.3 \\
\hline 62 & 25.4 & 29.0 & 95.6 & 83.3 & 18.9 & 21.4 & 52.7 & 55.1 & 4.7 & 4.3 \\
\hline 63 & 27.6 & 25.4 & 33.7 & 26.6 & 16.3 & 18.8 & 55.4 & 60.3 & 3.9 & 4.0 \\
\hline 64 & 26.19 & 28.4 & 79.2 & 81.6 & 17.79 & 19.38 & 55.8 & 56.3 & 4.4 & 4.0 \\
\hline D. Ort. & 29.9 & 26.3 & 71.8 & 68.5 & 17.8 & 20.1 & 56.1 & 52.9 & 4.6 & 4.8 \\
\hline
\end{tabular}


verimi ile 7 nolu genotip 1. sırada yer alırken bunu $832.3 \mathrm{~kg} / \mathrm{da}$ ile $11 \mathrm{nolu}, 828.2 \mathrm{~kg} / \mathrm{da}$ ile 22 ve $823.5 \mathrm{~kg} / \mathrm{da}$ ile 21 nolu genotipler takip etmiștir. $369.7 \mathrm{~kg} / \mathrm{da}$ tane verimi ile 51 nolu genotip en düșük tane verimine ulașmıștır. Edirne lokasyonundaki genotiplerin tane verimleri $116.4-751.3 \mathrm{~kg} / \mathrm{da}$ arasında değișim göstermiș, $751.3 \mathrm{~kg} / \mathrm{da}$ tane verimi ile $15 \mathrm{nolu}$ genotip 1. sırada yer alırken bunu $720.0 \mathrm{~kg} /$ da ile 44 nolu, $718.7 \mathrm{~kg} / \mathrm{da}$ ile 41 ve 715.2 $\mathrm{kg} / \mathrm{da}$ ile 8 nolu genotipler takip etmiștir. Tane verimi $116.4 \mathrm{~kg} / \mathrm{da}$ ile 52 nolu genotip en düșük tane verimine ulașmıștır. Yaptığımız çalıșmaya benzer șekilde, tane verimi yönünden genotipler arasındaki farkların önemli olduğunu belirtmișlerdir (Yağbasanlar ve ark., 1991; Sarı ve İmamoğlu, 2011; Sarı ve ark., 2012, Kahraman ve ark., 2012; Kahraman ve ark., 2013, Kahraman ve ark., 2015). Tane verimi yönünden, Gül ve ark. (1999), İnan ve ark. (2005), Kara ve ark. (2007), Mut ve ark. (2011), Erbaș ve Mut, (2013), ve Dumlupınar ve ark. (2013)'nın sonuçları genotiplerin ve deneme șartlarının farklı olmasından dolayı verimler arasında farklılıklar gözlemlenmiștir.

Genotiplerin bin tane ağırlığı Kırklareli lokasyonunda22.2-41.4 g, Edirnelokasyonunda ise 23.1-39.4 g arasında değișmiștir ve her iki lokasyonun benzer sonuçlar verdiği görülmüștür. Lokasyonlar açısından ortalama bin tane ağırlı̆ı̆ Kırklareli için $31.6 \mathrm{~g}$, Edirne için $31.7 \mathrm{~g}$ olarak belirlenmiștir. İnsan besleme olarak kullanılacak yulaflarda bin tane ağırlığının 26 g'dan yüksek olması istenmektedir. Bin tane ağırı̆̆ı yönünden elde ettiğimiz sonuçlar, Gül ve ark. (1999), Kara ve ark. (2007), Sarı ve İmamoğlu (2011), Sarı ve ark. (2012), Kahraman ve ark. (2012), Kahraman ve ark. (2013), Erbaș ve Mut (2013), Dumlupınar ve ark. (2013), ve Kahraman ve ark. (2015)'nın bulgularıla benzerlik göstermiștir.

Kırklareli lokasyonunda hektolitre ağırlığı 48.2-58.6 kg/hl, Edirne lokasyonunda ise 44.6-56.7 kg/hl arasında değișmiștir. Tüm genotiplerin hektolitre ağırlığı ortalaması Kırklareli'nde $52.5 \mathrm{~kg} / \mathrm{hl}$, ve Edirne'de $52.0 \mathrm{~kg} /$ $\mathrm{hl}$ olarak belirlenmiștir. Kırklareli'nde hektolitre ağırlı̆ı yönünden Kahraman standardını geçen hat olmamıștır, Edirne'de ise 49.55 ve 32 nolu hatlar Kırklar standardını geçmiștir.
Sarı ve İmamoğlu (2011), Sarı ve ark. (2012), Kahraman ve ark. (2012); Kahraman ve ark. (2013), Kahraman ve ark. (2015)'nın çalıșma sonuçları benzerlik gösterirken, Mut ve ark. (2011), ile Erbaș ve Mut (2013)'ın çalıșmaları farklılık göstermiștir. Genotiplerin genetik yapısı hektolitre ağırlığı üzerine etkisi çevreden daha fazla olup kullanılan genotiplerin hektolitre ağılıklarından dolayı sonuçlar farklı olmuștur.

Kırklareli lokasyonunda genotiplerin kavuz oranı \%20.6-39.2 arasında değișmiștir ve lokasyon ortalaması \%29.9 olmuștur. Edirne lokasyonunda genotiplerin kavuz oranı \%17.0-39.5 arasında değișmiștir ve lokasyon ortalaması \%26.3 olmuștur. İnsan beslenmesinde kullanılacak yulafların iç oranın fazla kavuz oranın ise az olması istenmektedir. Gıda sanayicisi kaliteli ürün elde edebilmek için kavuz oranı düșük, kavuzu kolay ayrılabilir ve randımanı yüksek yulaf talep etmektedir. Tane iç oranı yönünden elde ettiğimiz sonuçlar, Erbaș ve Mut (2013), Kahraman ve ark. (2016), ve Kahraman ve ark. (2017)'nın bulgularıla benzerlik göstermiștir.

Genotiplerin $2.2 \mathrm{~mm}$ elek üstü miktarları Kırklareli lokasyonunda 20.0-96.3, Edirne lokasyonunda ise \%23.1-95.4 arasında olmuștur. Elek değerleri tane iriliği ile ilișkili olup 1000 tane ağırlı̆ı̆ yüksek genotiplerin 2.2 $\mathrm{mm}$ elek üstü değerleri de yüksek olmaktadır. Insan beslenmesinde kullanılacak genotiplerin $2 \mathrm{~mm}$ elek üstü değerinin en az \%50 olması istenmektedir. Elek değeri yüksek yulafların kavuzlarının soyulup ezilmesi daha kolay olduğundan bu çeșitler tercih edilmelidir. Elek üstü değeri $(2.2 \mathrm{~mm})$ yönünden elde ettiğimiz sonuçlar, Kahraman ve ark. (2016), ve Kahraman ve ark. (2017)'nın bulgularıla benzerlik göstermiștir.

Kavuzu soyulmuș yulaf tam tane unlarının protein miktarının Edirne lokasyonunda Kırklareli lokasyonuna göre daha yüksek olduğu belirlenmiștir. Protein miktarı Kırklareli lokasyonunda \%14.5-20.2 Edirne lokasyonunda ise \%17.3-22.4 arasında değișim göstermiștir ve lokasyon ortalamaları sırasıyla \%17.8 ve \%20.1 olmuștur. Edirne lokasyonundaki genotiplerin protein oranları Kırklareli lokasyonundan daha yüksek olmuștur. Amaç ister hayvan yemi isterse insan beslenmesi olsun geliștirilecek yulafların 
protein miktarının yüksek olması istenmektedir. Protein oranı yönünden elde ettiğimiz sonuçlar, Yıldız ve ark. (2012), Kahraman ve ark. (2012), Sarı ve ark. (2012), Erbaș ve Mut (2013), Kahraman ve ark. (2015), ve Kahraman ve ark. (2016) farklı sonuçlar bulmușlardır. Yulafın kalitesi bitkinin yetiștirildiği ekolojik koșullar, çeșit ve hasat sonrası ișlemler gibi pek çok faktöre bağıı olarak değișir. Protein oranlarının bu kadar farklı olması yulafların kavuzları soyulduktan sonra tam yulaf tanesinde protein analizleri yapılmıștır.

Kırklareli lokasyonunda genotiplerin nișasta miktarı \%49.5-61.2 arasında değișirken lokasyon ortalaması \%56.1 olmuștur. Edirne lokasyonunda genotiplerin nișasta miktarı \%47.7-57.3 arasında değișmiștir ve lokasyon ortalaması \%52.9 olmuștur. İnsan beslenmesinde kullanılacak yulafların nișasta moktarının düșük olması istenmektedir. Nișasta miktarı yönünden elde ettiğimiz sonuçlar Yıldız ve ark. (2012), Sarı ve ark. (2012)'nın bulgularıyla benzerlik göstermiștir.

$\beta$-glukanın kolestrol, insülin ve glikoz düșürücü etkisi Tip 2 diyabet ve kalp damar hastalıkları riskini azaltmaktadır. $\beta$-glukan'ın kolestrol, insülin ve glikoz düșürücü etkisi barsak içeriğinin viskoziteni düșürmesine bağlanmaktadır. Molekül ağırlı̆̆ı, yapısı ve konsantrasyonu polisakkarit çözeltilerinin viskozitesi üzerine etki eden önemli faktörler olup $\beta$-glukanın besleyici özelliğini belirlemektedir. $\beta$-glukanın molekül ağırlığı üzerine çevresel faktörlerin, $\beta$-glukan miktarı üzerine ise

\section{Kaynaklar}

Aman P., and Graham H., 1987. Analysis of total and insoluble mixed-linked $(1 \rightarrow 3),(1 \rightarrow 4)-\beta$-Dglucans in barley and oats. J Agric Food Chem. 35, 1:704-709. doi: 10.1021/jf00077a016

Anderson, C., 2000. Genetic analysis of oil content and composition in oat (Avena sativa L.). Master of Science Thesis Department of Botany, University of Manitoba, Winnipeg, Manitoba

Andersson A.A.M., and Börjesdotter, D., 2011. Effects of environment and variety on content and molecular weight of $\beta$-glucan in oats. Journal of Cereal Science 54: 122-128

Anonim, 2009. Cereals - Determination of Bulk Density, Called Mass per Hectolitre, Part 3: Rutine method. TS ISO 7971-3, Türk Standartları Enstitüsü, Ankara çeșit etkisinin önemli olduğu gösterilmiștir (Andersson and Börjesdotter, 2011). $\beta$-glukan Kırklareli lokasyonunda genotiplerin $\beta$-glukan \%3.5-5.9 arasında değișirken lokasyon ortalaması \% 4.6 olmuștur. Edirne lokasyonunda ise genotiplerin $\beta$-glukan \%3.9-5.8 arasında değișirken lokasyon ortalaması \%4.8 olmuștur. Insan beslenmesinde kullanılacak yulafların $\beta$-glukanın yüksek olması istenmektedir. $\beta$-glukan yönünden elde ettiğimiz sonuçlar Sikora et al. (2013), Redaelli et al. (2013)'nin bulgularıyla benzerlik gösterirken Aman and Graham (1987), Saastamoinen et al. (1992), Yıldız ve ark. (2012), Sarı ve ark. (2012), ve Sarı ve Ünay (2013)'ın bulgularıyla farklılık göstermiștir.

\section{Sonuç}

Tane verimi ve incelenen kalite özellikleri yönünden Kırklareli lokasyonunda; 11, 14, 15, 16, 21 ve 22 nolu hatlar ile Kahraman çeșidi, Edirne lokasyonunda ise 11, 14, 15, 16 ve 38 nolu hatlar ile Kahraman çeșidi öne çıkmıștır. Trakya-Marmara Bölgesinde insan beslenmesine açısından 11, 14, 15 ve 16 nolu hatlar ile Kahraman çeșidinin uygun olduğu belirlenmiștir.

\section{Teșekkür}

Bu çalıșma, TÜBiTAK-1003 20140040 nolu “insan Beslenmesine Uygun Yulaf Çeșitlerinin Geliștirilmesi" projesinin bir bölümünü içermektedir. Projeyi destekleyen TÜBiTAK'a katkılarından dolayı teșekkürlerimizi sunarı.

Anonim, 2014. FAOSTAT-Agriculture, http://www. fao.org (Erișim tarihi: 24.07.2017)

Buerstmayr H., Krenn N., Stephan U., Grausgruber, H., and Zechner E., 2007. Agronomic performance and quality of oat (Avena sativa L.) genotypes of worldwide origin produced under Central European growing conditions. Field Crops Res, (101): 341-351

Doehlert D.C., McMullen M.S., and Hammond J.J., 2001. Genotypic and environmental effects on grain yield and quality of oat grown in North Dakota. Crop Science 41:1066-1072

Dumlupınar Z., Maral H., Yıldırım M., Gezginç H., Dokuyucu T. ve Akkaya A., 2013. Bazı Ümitvar Yulaf Hatlarının Tarımsal Özellikler Bakımından Değerlendirilmesi. Türkiye 10. Tarla Bitkileri Kongresi 10-13 Eylül, Selçuk Üniversitesi, Ziraat Fakültesi, Konya, (Poster Bildiri) 121-125 
Erbaș Ö.D. ve Mut Z., 2013. Saf Hat Yulaf Genotiplerinin Tarımsal ve Bazı Kalite Özelliklerinin Belirlenmesi. Türkiye 10. Tarla Bitkileri Kongresi 10-13 Eylül, Selçuk Üni. Zir. Fak. Konya, 821-828

Gül İ., Akıncı, C. ve Çölkesen M., 1999. Diyarbakır koșullarında uygun tane ve ot amaçlı yetiștirilebilecek yulaf çeșitlerinin belirlenmesi. Orta Anadolu'da Hububat Tarımının Sorunları ve Çözüm Yolları Sempozyumu, s: 117-125, 8-11 Haziran, Konya

İnan A.S., Özbaș M.O. ve Çağırgan M.İ., 2005. İnsan beslenmesinde kullanılan yulaf hatlarının tarımsal ve kalite özelikleri bakımından değerlendirilmesi. Türkiye VI. Tarla Bitkileri Kongresi. Cilt II: 11531155. 5-6 Eylül 2005, Antalya

Kahraman T., Avcı R., Öztürk İ. ve Tülek A., 2012. Trakya-Marmara Bölgesine Uygun Yulaf Genotiplerinin Belirlenmesi. Research Journal of Agricultural Sciences (TABAD) Tarım Bilimleri Araștırma Dergisi. Tarım Sempozyumu Özel Sayısı (Prof. Dr. Selahattin İptaș anısına) 5 (2): 24-28

Kahraman T., Avcı R. ve Tülek A., 2013. Yulaf (Avena sativa L.) Genotiplerinde Tane Verimi ve Bazı Kalite Özellikleri Üzerine Çeșit ve Çevrenin Etkileri. Türkiye 10. Tarla Bitkileri Kongresi 1013 Eylül, Selçuk Üniversitesi, Ziraat Fakültesi, Konya, s. 39-44

Kahraman T., Avcı R. ve Kurt C. 2015. TrakyaMarmara Bölgesinde Bazı Yulaf (Avene sativa L.) Genotiplerinin Tane Verimi, Kalite ve Tarımsal Özelliklerinin Araștırılması. 11. Tarla Bitkileri Kongresi, 7-10 Eylül, Çanakkale, s. 204-207

Kahraman T., Dumlupınar Z. ve Kurt C., 2016. Evaluation of some oat (Avene sativa L.) genotypes for yield and selected quality parameters grown under Trakya-Marmara region of Turkey. The 10th Anniversary International Oat Conference, July 11 - 15, 2016 St. Petersburg, Russia. p. 119

Kahraman T., Kurt C., Subașı A. ve Sanal T., 2017. Evaluation of Some Oat (Avena sativa L.) Genotypes in Terms of Human Nutrition Grown under Trakya-Marmara Region. 2. International Balkan Agriculture Congress, 16-18 May 2017, Tekirdağ, Turkey p. 236

Kara R., Dumlupınar Z., Hıșır Y., Dokuyucu T. ve Akkaya A., 2007. Kahramanmaraș Koșullarında Yulaf Çeșitlerinin Tane Verimi ve Verim Unsurları Bakımından Değerlendirilmesi. Türkiye VII. Tarla Bitkileri Kongresi, 25-27 Haziran 2007, Erzurum. s.121-125
Mut Z., Akay H., Sezer İ., Gülümser A., Öner F. ve Erbașı Ö.D., 2011. Farklı Orijinli Yulaf (Avena sativa I.) Genotiplerinin Samsun Ekolojik Kosullarında Tarımsal ve Bazı Kalite Özelliklerinin Tespiti. 9. Tarla Bitkileri Kongresi 12-15 Eylül 2011 Bursa. Tahıllar ve Yemeklik Tane Baklagiller Cilt I. s.88-93

Peterson D.M., Wesenberg D.M., Burrup D.E., and Erickson C.A., 2005. Relationships among agronomic traits and grain composition in oat genotypes grown in different environments. Crop Sci. 45: 1249-1255

Redaelli R., Del Frate V., Bellato S., Terracciano G., Ciccoritti R., Germeier C.U., De Stefanis E., and Sgrulletta D., 2013. Genetic and environmental variability in total and soluble $\beta$-glucan in European oat genotypes. J. Cereal Sci. 57: 193:199. doi: 10.1016/j.jcs.2012.09.003

Saastamoinen M., Plaami S., and Kumpulainen J.A., 1992. Genetic and environmental variation in B-glucan content of oats cultivated or tested in Finland. Journal of Cereal Science, 16:279290. doi: 10.1016/S0733-5210(09)80090-8

Sarı N. ve İmamoğlu A., 2011. Menemen Ekolojik Koșullarına Uygun Yulaf Hatlarının Belirlenmesi. Anadolu Ege Tarımsal Araștırma Enstitüsü Dergisi 21 (1): 16-25

Sarı N., İmamoğlu A. ve Yıldız Ö., 2012. Menemen Ekolojik Koșullarında Bazı Ümitvar Yulaf Hatlarının Verim ve Kalite Özellikleri. ANADOLU (Sayı :1) 2012-18

Sarı N. ve Ünay A., 2013. Bazı Yulaf Genotiplerinin Beta Glukan İçeriğinin Kümeleme Analizi ile Değerlendirilmesi. Tarla Bitkileri Merkez Araștırma Enstitüsü Dergisi, 2013, 22 (1): 6-12

Sikora P., Tosh S.M., Brummer Y., and Olsson O., 2013. Identification of high beta-glucan oat lines and localization and chemical characterization of their seed kernel beta-glucans. Food Chemistry, 137: 83-91

Tamm I., 2003. Genetic and Environmental Variation of Grain Yield of Oat Varieties. Agronomy Research, 1(1):93-97

Yağbasanlar T., Çölkesen M., ve Kırtok Y., 1990. Çukurova Koșullarında Bazı Yulaf Çeșitlerinin Bașlıca Tarımsal Özellikleri Üzerinde Bir Araștırma. Ç. Ü. Zir. Fak. Dergisi, 6(1): 95-110

Yıldız O., Sarı N., Büyükkileci C. ve İmamoğlu A., 2012. Evaluation of advanced oat lines in Aegean Region in terms of constituents affecting biscuit quality. $23^{\text {rd }}$ International Scientific-Experts Congress on Agriculture and Food Industry, September 27-29, 144 